\title{
Isoform-specific loss of dystonin causes hereditary motor and sensory neuropathy
}

William W. Motley, MD, DPhil, Stephan Züchner, MD, PhD, and Steven S. Scherer, MD, PhD

Neurol Genet 2020;6:e496. doi:10.1212/NXG.0000000000000496

\section{Abstract}

\section{Objective}

To determine the genetic cause of axonal Charcot-Marie-Tooth disease in a small family with 2 affected siblings, one of whom had cerebellar features on examination.

\section{Methods}

Whole-exome sequencing of genomic DNA and analysis for recessively inherited mutations; PCR-based messenger RNA/complementary DNA analysis of transcripts to characterize the effects of variants identified by exome sequencing.

\section{Results}

We identified compound heterozygous mutations in dystonin (DST), which is alternatively spliced to create many plakin family linker proteins (named the bullous pemphigoid antigen 1 [BPAG1] proteins) that function to bridge cytoskeletal filament networks. One mutation $(c .250 \mathrm{C}>\mathrm{T})$ is predicted to cause a nonsense mutation (p.R84X) that only affects isoform 2 variants, which have an $\mathrm{N}$-terminal transmembrane domain; the other $(\mathrm{c} .8283+1 \mathrm{G}>\mathrm{A})$ mutates a consensus splice donor site and results in a 22 amino acid in-frame deletion in the spectrin repeat domain of all BPAG1a and BPAG1b isoforms.

\section{Conclusions}

These findings introduce a novel human phenotype, axonal Charcot-Marie-Tooth, of recessive DST mutations, and provide further evidence that BPAG1 plays an essential role in axonal health.
Correspondence

Dr. Motley

wmotley@thirdrockventures.com

From the Department of Neurology (W.W.M., S.S.S.), Perelman School of Medicine, University of Pennsylvania, Philadelphia; and Department of Human Genetics (S.Z.), Hussman Institute for Human Genomics, University of Miami, FL. 


\section{Glossary}

cDNA $=$ complementary DNA; CMT $=$ Charcot-Marie-Tooth; MRC $=$ Medical Research Council; SR $=$ spectrin repeat; WES $=$ whole-exome sequencing.

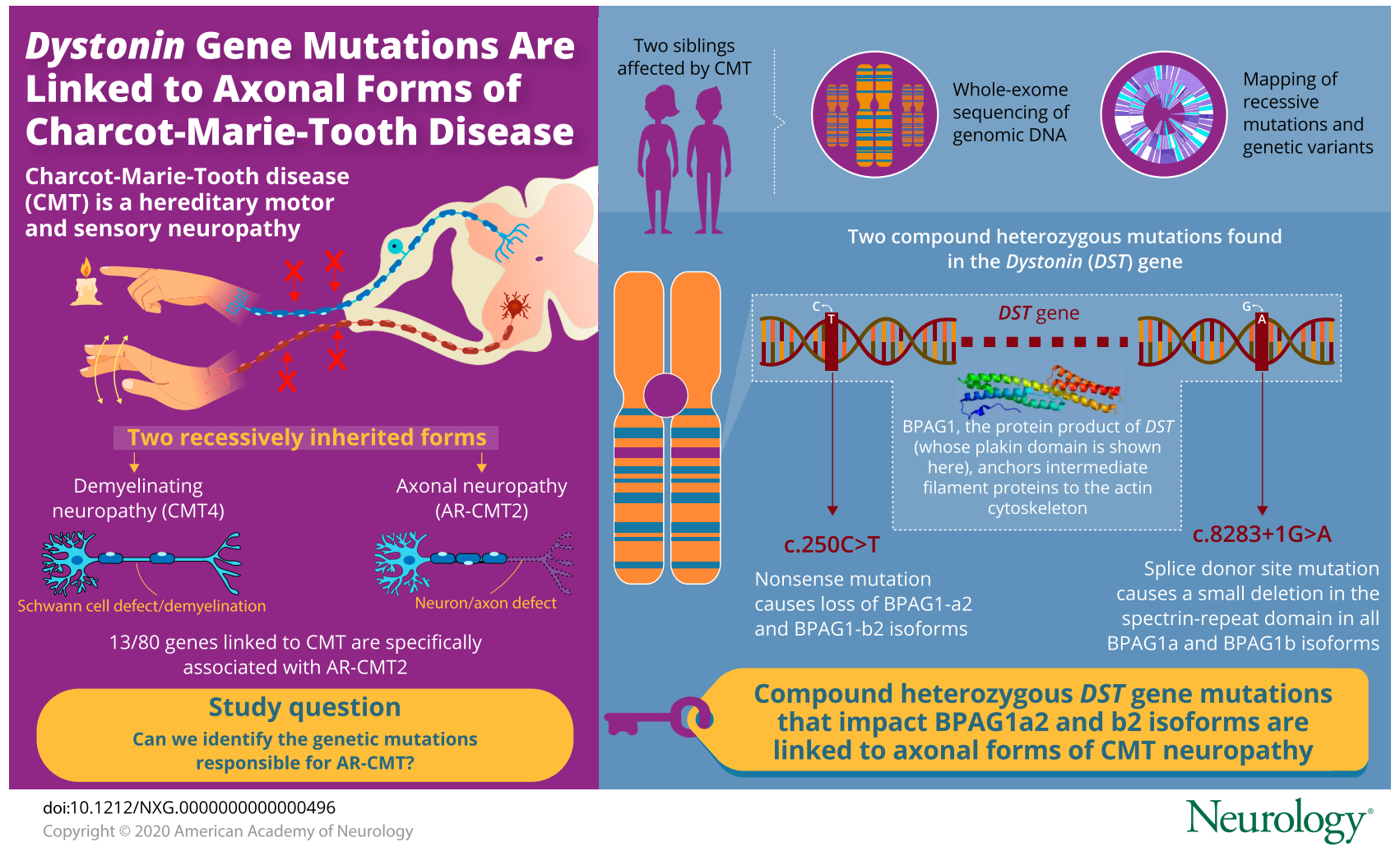

Charcot-Marie-Tooth (CMT) disease, also called hereditary motor and sensory neuropathy, is among the most common neurogenetic diseases and is characterized by progressive length-dependent weakness and sensory loss. CMT is divided into demyelinating (type 1) and axonal (type 2) forms of the disease based on clinical, electrophysiologic, histologic, and genetic features. ${ }^{1}$ Recessively inherited demyelinating neuropathies are called CMT4, whereas recessively inherited axonal neuropathies are called autosomal recessive (AR)-CMT (ncbi.nlm.nih.gov/omim/). Over 80 genes have been linked to CMT and related disorders; 13 of which have been associated with AR-CMT2.

Next-generation DNA sequencing has facilitated the identification of disease-causing mutations in small families with $\mathrm{CMT}^{2}$ To determine the cause of AR-CMT in a small family with 2 affected individuals, we performed wholeexome sequencing (WES) and identified 2 rare compound heterozygous variants in the dystonin gene (DST; MIM: $113810)$. The protein product of the DST gene is an alternatively spliced cytoskeletal linker protein named the bullous pemphigoid antigen 1 (BPAG1), so named because one of its isoforms (BPAG1-e) is the autoimmune target in the blistering skin disease. ${ }^{3}$ Two human genetic diseases have been linked to mutations in DST: recessively inherited mutations in DST that only affect the BPAG1-e isoforms cause epidermolysis bullosa simplex (EBSB2), ${ }^{4,5}$ and recessively inherited mutations cause hereditary sensory and autonomic neuropathy (all referred to as HSAN-VI), the severity of which depends on the isoforms that are affected. ${ }^{6-10}$ Here, we characterize the mutations identified in 2 patients with an axonal neuropathy caused by mutations in DST and show that together they selectively affect BPAG1-a2 and BPAG1-b2 isoforms. This work identifies a novel cause of AR-CMT, introduces a novel phenotype for DST-linked axonopathies, and supports an essential role of BPAG1 in axonal health.

\section{Methods}

\section{Protocol approvals and patient consents}

Institutional Review Board approval was obtained from the University of Pennsylvania for these studies. Written informed consent was obtained from each patient who participated.

\section{Clinical data and sample collection}

Each living family member was seen by S.S.S. in an outpatient clinic, where an examination using the Medical Research 
Council (MRC) scale for strength was used, and clinical neurophysiology was also performed with standard methods.

\section{WES and analysis}

Genomic DNA was isolated from peripheral blood from all participants. Exome DNA was captured using the SureSelect, Human All Exon5 $50 \mathrm{Mb}$ kit (Agilent, Santa Clara, CA) and sequenced on a HiSeq 2000 (Illumina, San Diego, CA). Paired-end reads of $100 \mathrm{bp}$ length were generated, and alignment and variant calls were made using $\mathrm{BWA}^{11}$ and genome analysis toolkit software packages. ${ }^{12}$ Using Genesis, ${ }^{13}$ variants were filtered for missense, nonsense, frameshift, stop gained or lost, splice site variants, deletions, and insertions that met the following criteria: high evolutionary conservation scores (if a missense mutation: PhastCons $>0.5$, phyloP $>$ 1.5), low allele frequencies in large data sets $(<0.01$ in ExAC and gnom $\mathrm{AD},<0.002$ in Genesis), and good sequence quality (read depth $>12$, genome quality filter GQ $>75$, and quality filter QUAL > 50), which segregated with disease in a recessive inheritance pattern. Two missense changes (p.Pro2950Ser and p.Ile559Val) in the REV3L gene, which encodes a DNA polymerase zeta subunit protein, cosegregated but were present in gnomAD in 3 and 125 individuals, respectively. The DST variants were confirmed by bidirectional Sanger sequencing.

\section{Transcript analysis}

RNA was isolated from skin using the ZR-Duet DNA/RNA MiniPrep Plus kit (Zymo, Irvine, CA). Complementary DNA (cDNA) was reverse transcribed using SuperScript III FirstStrand Synthesis System (Invitrogen, Waltham, MA). cDNA was PCR amplified using Platinum Taq (Invitrogen) using forward ( $5^{\prime}$-GTTCCAGACTGTAGAGGCCCAATTG-3') and reverse (5'-GCTGAAATTGATGAGAGCTTGCACA- ${ }^{\prime}$ ) primers. The BPAG1-e isoform was amplified using forward ( $5^{\prime}$-TGCAGCAAGGGCAGCACATGGAAGCA- $\left.3^{\prime}\right)$ and reverse ( $5^{\prime}$ GCCTGGCAGTCACAGTGTGCCTAAGCC-3') primers. $\beta$-tubulin (TUBB) was amplified using forward ( $5^{\prime}$ CTGTTCGCTCAGGTCCTTTTGG-3') and reverse (5'GGTGTGGTCAGCTTCAGAGTGC-3') primers. Mutant transcript sequence was isolated after PCR products were cloned using TOPO TA Cloning Kit for Sequencing and Sanger sequenced using traditional methods.

\section{Mutation mapping}

Our description of the 2 mutations observed in our patients follows Human Genome Variation Society nomenclature guidelines (hgvs.org/mutnomen) and is based on sequence from the following transcripts: our mutations are annotated based on BPAG1-a2, RefSeq transcript NM_001144769; the HSAN-VI mutations are also annotated based on BPAG1-a2, RefSeq transcript NM_001144769; and the EBSB2 mutations are annotated based on BPAG1-e, RefSeq transcript NM 001723. The location and number of predicted spectrinrepeat (SR) domains were determined based on previous publications ${ }^{14,15}$ and personal communications with the authors. The SR domain structure from the plakin domain was downloaded from the Protein Data Bank (accession number $\left.2 \mathrm{IAK}^{16}\right)$ and viewed and annotated using PyMol software (pymol.org).

\section{Results}

\section{Clinical data}

Our proband (II.3) first noted difficulty walking at age 13 years, difficulty with balance at age 15 years, and required foot orthotics at age 20 years. She was first seen in our clinic at age 29 years, when she was diagnosed with axonal CMT. At that time, she was unable to plantar flex, dorsiflex, or evert the foot at the ankles (MRC, 0/5), and the posterior and anterior compartment muscles of the calves had marked atrophy. Proximal leg muscles were strong. In the upper extremities, there was moderate weakness $(4 / 5)$ and mild atrophy of the interosseous and thenar muscles and slight weakness of finger extension. There was decreased appreciation to pin prick and light touch until above the ankles and a mild proprioceptive deficit. Deep tendon reflexes were absent at the ankles, $1+$ at the knees, and 2+ at the triceps and biceps. Plantar responses were muted. She had a positive Romberg sign and had significant difficulty with tandem walking and had been wearing leg braces for several years-without these braces, she walked with a steppage gait. Weakness of intrinsic hand muscles had progressed to $4-/ 5$ by 1999 , and mild weakness of the quadriceps and hamstrings was noted. Falling became an issue at age 51 years; at age 53 years, she started using a cane and progressed to using a walker by age 55 years. From 2010 to 2019, her CMT neuropathy score increased from 23 to $29 .{ }^{17}$ EMGs were performed at age 29, 35, 45, and 64 years (table 1 ), showing progressively smaller amplitudes of the sensory and motor compound action potentials. Thus, she has a length-dependent, sensory and motor axonal neuropathy that worsened over time.

She also developed some additional findings. She had an abnormal electronystagmogram at age 30 years, with saccadic pursuit movements, but these were not evident on clinical examination at that time, and brainstem auditory evoked potentials were normal. At age 49 years, she had scanning speech, eye movements with broken smooth pursuits, and abnormal finger-to-nose and rapid alternating movements in the hands, all indicative of a cerebellar disorder. Nystagmus in primary gaze and scanning speech were noted at age 56 years. Brain MRI at age 60 years was normal; it did not show cerebellar atrophy (not shown).

Her younger brother (II.4) has been followed in our clinic since 2003, when he was aged 46 years. He had been diagnosed with CMT around age 18 years with a similar clinical course. At age 47 years, he was noted to have difficulty executing rapid alternating movements with his hands and trouble performing heel-to-shin movements. He has not developed abnormal eye movements or scanning speech. From 2010 to 2019, his CMT neuropathy score increased from 21 
Table 1 Nerve conduction studies of affected patients

\begin{tabular}{|c|c|c|c|c|c|c|c|c|c|c|c|c|c|c|c|c|}
\hline \multirow[b]{2}{*}{ Sensory } & \multicolumn{2}{|c|}{ II.3 (1984) (age 29 y) } & \multicolumn{2}{|c|}{ II.3 (2001) (age 45 y) } & \multicolumn{2}{|c|}{ II.3 (2010) (age 55 y) } & \multicolumn{2}{|c|}{ II.3 (2019) (age 64 y) } & \multicolumn{2}{|c|}{ II.4 (2003) (age 46 y) } & \multicolumn{2}{|c|}{ II.4 (2010) (age 53 y) } & \multicolumn{2}{|c|}{ II.4 (2019) (age 62 y) } & \multicolumn{2}{|c|}{ Normal values } \\
\hline & $\mu \mathrm{V}$ & m/second & $\mu \mathrm{V}$ & $\mathrm{m} /$ second & $\mu \mathrm{V}$ & m/second & $\mu \mathrm{V}$ & $\mathrm{m} /$ second & $\mu \mathrm{V}$ & $\mathrm{m} /$ second & $\mu \mathrm{V}$ & $\mathrm{m} /$ second & $\mu \mathrm{V}$ & $\mathrm{m} /$ second & $\mu \mathrm{V}$ & $\mathrm{m} / \mathrm{second}$ \\
\hline Radial & 11 & 51.3 & 2.2 & 53 & NR & NR & - & - & NR & NR & NR & NR & - & - & $\geq 15$ & $\geq 50$ \\
\hline R median ${ }^{a}$ & 2.0 & 52.3 & 1.9 & 40 & - & - & - & - & $N R$ & NR & $N R$ & NR & - & - & $\geq 10$ & $\geq 50$ \\
\hline$U^{\prime} a^{a}{ }^{a}$ & - & - & $N R$ & NR & - & - & - & - & NR & NR & NR & NR & - & - & $\geq 7$ & $\geq 50$ \\
\hline \multirow[t]{2}{*}{ Sural } & NR & NR & NR & NR & NR & NR & - & - & - & - & NR & NR & - & - & $\geq 6$ & $\geq 40$ \\
\hline & \multicolumn{2}{|c|}{ II.3 (1984) (age 29 y) } & \multicolumn{2}{|c|}{ II.3 (2001) (age 45 y) } & \multicolumn{2}{|c|}{ II.3 (2010) (age 55 y) } & \multicolumn{2}{|c|}{ II.3 (2019) (age 64 y) } & \multicolumn{2}{|c|}{ II.4 (2003) (age 46 y) } & \multicolumn{2}{|c|}{ II.4 (2010) (age 53 y) } & \multicolumn{2}{|c|}{ II.4 (2019) (age 62 y) } & \multicolumn{2}{|c|}{ Normal values } \\
\hline Motor $^{\mathbf{b}}$ & $\mathrm{mV}$ & $\mathrm{m} /$ second & $\mathrm{mV}$ & $\mathrm{m} / \mathrm{second}$ & $\mathrm{mV}$ & $\mathrm{m} /$ second & $\mathrm{mV}$ & $\mathrm{m} / \mathrm{second}$ & $\mathrm{mV}$ & $\mathrm{m} / \mathrm{second}$ & $\mathrm{mV}$ & $\mathrm{m} / \mathrm{second}$ & $\mathrm{mV}$ & $\mathrm{m} /$ second & $\mathrm{mV}$ & $\mathrm{m} / \mathrm{sec}$ ond \\
\hline Peroneal $^{c}$ & $\mathrm{NR}$ & NR & NR & NR & - & - & - & - & - & - & NR & NR & - & - & $\geq 2.0$ & $\geq 41$ \\
\hline Median & 6.0 & 47.0 & 1.9 & 42 & 0.1 & 36 & - & - & NR & NR & NR & NR & - & - & $\geq 4.0$ & $\geq 49$ \\
\hline Ulnar & 7.0 & 48.2 & 3.9 & 47 & 2.1 & 44 & 1.4 & 57 & 5.3 & 44 & 4.7 & 43 & 2.0 & 47 & $\geq 6.0$ & $\geq 49$ \\
\hline
\end{tabular}

Abbreviations: - = not done; $\mathrm{NR}=$ no response.

a Orthodromic.

b The amplitudes of the distal motor responses are shown.

${ }^{c}$ Response to EDB. 
to 26 . EMGs were performed at age 46,53 , and 59 years (table 1) and show a severe, progressive, sensory, and motor axonal neuropathy. Their eldest sibling (II.1) and their father (I.1) were examined at separate times and did not have neuropathy.

\section{DST mutations}

We performed WES on all 3 living siblings. After sorting for variants based on stringency criteria, DST was the only gene with variants not present in gnom $\mathrm{AD}$ that cosegregated in a recessive inheritance pattern. One mutation (c.250C $>\mathrm{T}$; GRCh38 Chr6:56,900,588G $>\mathrm{A}$ ) is a nonsense mutation that is predicted to cause a premature termination of the protein (p.R84X); the other mutation (c.8283+1G $>A$; GRCh38: $56,557,318 \mathrm{C}>\mathrm{T}$ ) alters a consensus splice donor site. Both mutations are present in the 2 affected individuals (II.3 and II.4), whereas only $1(\mathrm{c} .250 \mathrm{C}>\mathrm{T})$ is present in the unaffected sibling (II.1), showing that the mutations are in trans (figure 1, $A$ and $B$ ). Neither variant is present in gnomAD, in the NHLBI exome variant server, or in the $\sim 13,000$ exomes in Genesis.

DST has a large (107 exons), highly complex gene structure that is similar in humans and mice. Four transcription initiation sites and alternative splicing produce 8 isoforms of BPAG1 (figures $1 \mathrm{C}$ and $2 \mathrm{~A}$ ). The most $5^{\prime}$ transcription initiation sites encode the $\mathrm{N}$-terminus of isoform variants BPAG1-a2 and BPAG1-b2, the only isoforms with a transmembrane domain. Because the p.R84X mutation is in 1 of the 4 exons that are related only to the BPAG1-a2 and BPAG1-b2 isoforms (figure 1C), it is predicted to cause the loss of the BPAG1-a2 and BPAG1-b2 isoforms and to not affect the other 6 isoforms (BPAG1-e, BPAG1-n, BPAG1-a1, BPAG1-a3, BPAG1-b1, and BPAG1-b3). The c.8283+1G>A variant lies in the GT dinucleotide splice donor site, 1 base pair downstream of exon 63 (numbered based on the entire genomic locus; this corresponds to exon 53 in the a 2 isoform), which encodes part of the SR domains that are present in all BPAG1-a and BPAG1-b transcripts (figure 2A).

To characterize further the $c .8283+1 \mathrm{G}>\mathrm{A}$ variant, we took advantage of the fact that some BPAG1 isoforms containing the affected SR domain are also expressed in skin. PCR amplification of cDNA from punch biopsies from patient skin and a control using primers flanking the splice site in the SR domain revealed a shorter transcript in both patients (figure 1D). Sequencing clones of this shorter transcript revealed a 66 bp deletion (c.8218 8283del, annotated based on transcript a2), showing that a cryptic dinucleotide splice site within the coding exon is used instead of the mutant splice site (figure $1 \mathrm{E}$ ); this is predicted to cause an inframe deletion of 22 amino acids (p.2740_2761del; figure 2A). Alignment of the SR domain affected by the deletion shows that it is highly conserved (figure 2B). SR domains are triple helical protein structures, often organized in tandem repeats to form long elongated cytoskeletal proteins; helix $\mathrm{C}$ from the previous $\mathrm{SR}$ is often contiguous with helix A. The region that is deleted in our patients contains the last 4 residues in helix $A$, the linker between helices $\mathrm{A}$ and $\mathrm{B}$, and the first 10 residues of helix $\mathrm{B}$. Although the SR domain mutated in our patients (SR12 based on sequences from an annotation with a total of 32 SR domains ${ }^{16}$ ) has not been crystalized, the SR domains in the plakin domain of mouse BPAG1 have been crystalized ${ }^{16}$ (residues 580-802, annotated based on protein NP_604443.2). Figure 2C shows an alignment of human SR12 and the human SR1 and SR2 (orthologous to the SR domains from mouse protein that have been crystalized), and figure $2 \mathrm{D}$ shows the position of the p.2740_2761del on this crystal structure.

\section{Discussion}

DST encodes BPAG1, which has multiple isoforms (even more than are shown in figure $2 \mathrm{~A}$ ) that are expressed in a cell type-specific manner. ${ }^{18}$ BPAG1-a, -b, -e, and -n were the first to be described; when 3 more $\mathrm{N}$-terminal variants were discovered (the result of alternative promoters), the terms 1,2 , and 3 were introduced for BPAG1-a and BPAG1-b isoforms (BPAG1-a1, -a2, and -a3; BPAG1-b1, -b2, and -b3; figure 2A). BPAG1 isoforms have varied functions, including cytoskeletal linker proteins with key functional domains connecting actin filaments, intermediate filaments, and microtubules, ${ }^{18}$ so that the loss of BPAG1 is thought to disrupt axonal transport through direct interactions with dynactin $\mathrm{p} 150^{\text {Glued }}{ }^{19}$ retrolinkin, ${ }^{20}$ and microtubule-associated protein $1 \mathrm{~B} .^{21}$

The p.R84X mutation is predicted to abolish the expression of BPAG1-a2 and BPAG1-b2, but not the other BPAG1 isoforms, which are initiated by downstream alternative promoters (figures 1 and 2). The messenger RNA containing this mutation would be predicted to be degraded by nonsense mediated decay. ${ }^{22}$ The c.8283+1G>A variant changes a consensus residue in a splice donor site, resulting in a 66 base pair/22 amino acid deletion in the SR domain that is predicted to affect all BPAG1-a and -b isoforms (-a1, -a2, -a3, -b1, $-b 2$, and -b3), but not BPAG1-e and -n (figure 2A). If this mutation produces an in-frame mutation, it may lead to hypofunction of BPAG1-a and BPAG1-b isoforms that play an essential role in primary sensory and motor neurons. With this in mind, it is particularly interesting that the mutation is adjacent to a putative ezrin-radixin-moesin domain ${ }^{18,19}$ that has been implicated as essential for axonal transport. ${ }^{19,20}$ Inframe deletion in SR domains can result in partial loss-offunction phenotypes: short deletions in the SR domain of dystrophin cause Becker muscular dystrophy, where truncating mutations cause the more severe Duchenne muscular dystrophy. $^{23}$

We described 2 siblings with a progressive, sensory and motor axonal neuropathy over 4 decades. Cerebellar clinical findings emerged later, and autonomic symptoms/signs were not apparent even after age 60 years. In keeping with the absence of blistering skin, seen in patients with recessive mutations in the coiled-coil domain of BPAG1-e and BPAG1-n isoforms, the mutations in our patients did not affect these isoforms (figure 2A). Conversely, patients with EBSB2 do not have neuropathy., ${ }^{4,24}$ 
Figure 1 Compound heterozygous DST variants segregate with neuropathy, and mapping the mutations in the DST gene structure predicts isoform-specific loss of function

A

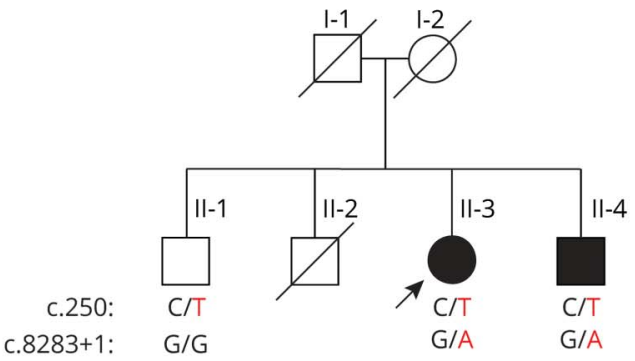

B

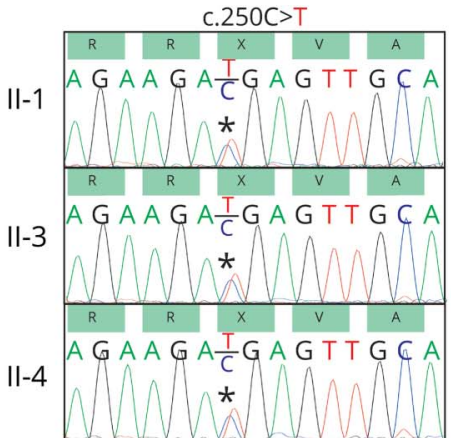

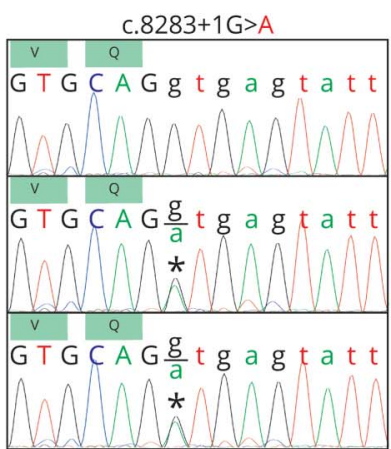

C
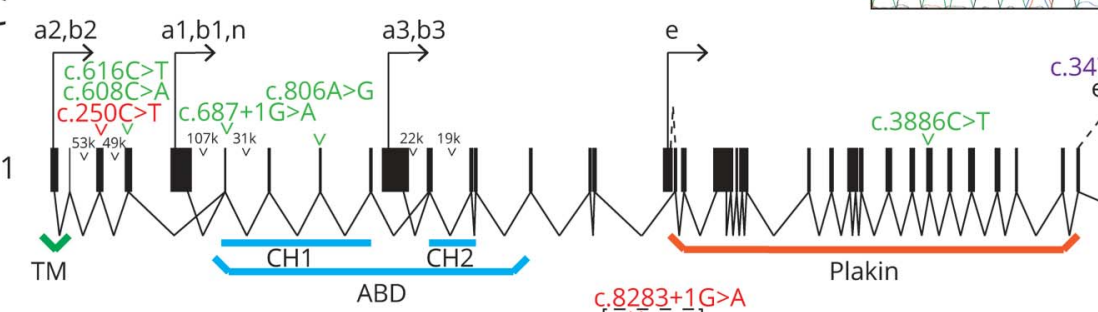

C.3478C $>T, 3853 A>T$
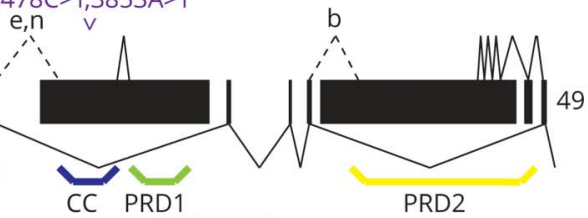

50
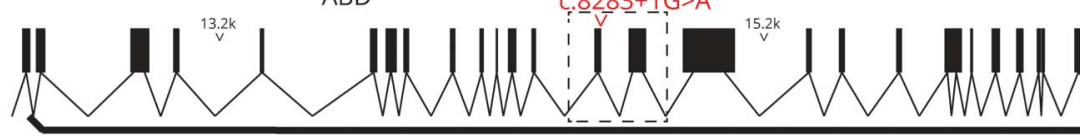

PRD2

89

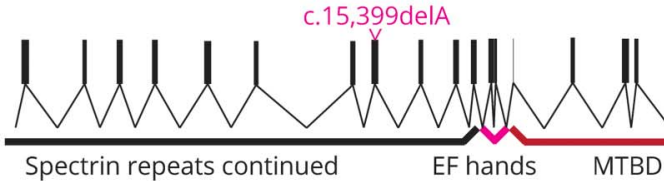

Spectrin repeats

D

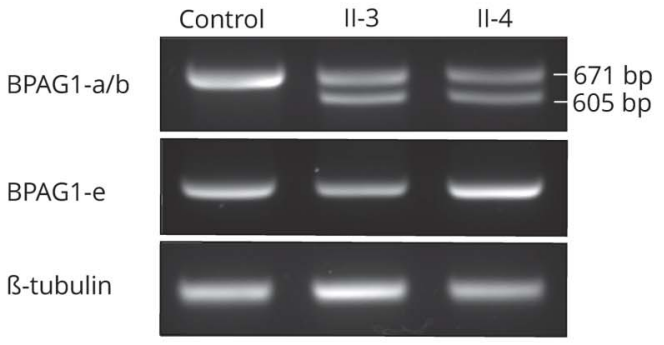

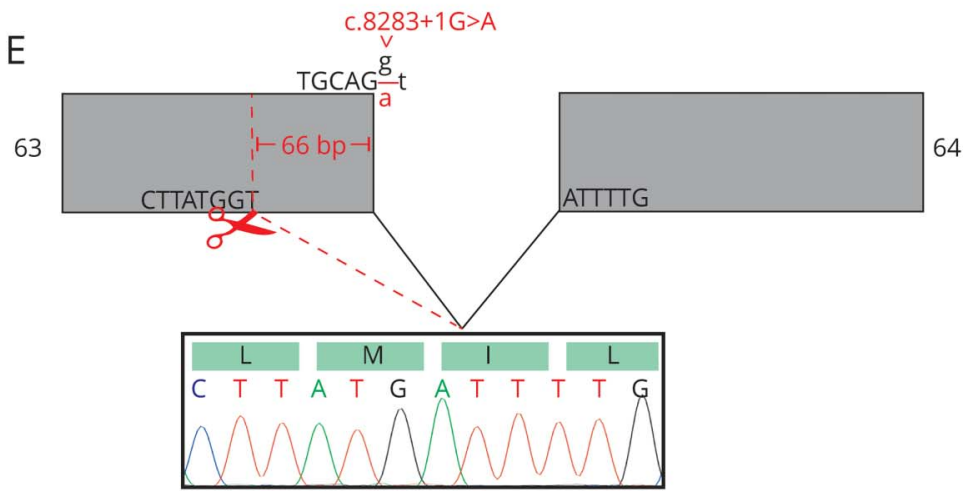

(A) The pedigree of the family. The proband (arrow) and her affected brother (II.3 and II.4, respectively) as well as their 2 unaffected older siblings (II.1 and II.2) and unaffected parents (I.1, I.2) are shown, along with the genotypes of all living members (II.1, II.3, and II.4). One mutation (c.250C>T) is present in all 3 siblings; the second mutation (c.8283+1G>A) is only present in the 2 affected individuals (II.3 and II.4). The segregation of these DST variants is consistent with recessive inheritance from their unaffected parents. (B) Sanger sequencing was used to confirm the genotypes gathered by whole-exome sequencing. The chromatograph traces of the 2 variants are shown for all 3 members of the family. (C) The exon structure of DST. Exons are numbered for the entire gene, not for specific transcripts; the width of the exons is proportional to their length. There are 107 exons and 4 transcription initiation sites, each of which gives rise to the named transcripts-1: a2, b2; 2: a1, b1, n; 3: a3, b3; 4 : e. The 4 alternative promoters and the 3 alternative splicing events (dotted lines) produce the 8 isoforms of BPAG1 shown in figure 2. The protein domains encoded by the exons are indicated with brackets below the exons (abbreviations are explained in figure 2 ). The genomic locations of the mutations identified in our patients are shown in red, the homozygous and compound heterozygous mutations associated with HSAN-VI are shown in magenta and green, respectively, and the mutations associated with EBSB2 are shown in purple. (D) PCR amplification of skin complementary DNA from a control and the 2 affected patients shows that the c.8283+1G>A mutation (part of the dinucleotide-gt-splice donor site at the 3 ' end of exon 63 ) results in incorrect splicing and deletion in the transcript. BPAG1-e and $\beta$-tubulin expression is similar between the control and patient samples. (E) Cloning and sequencing of that aberrant transcript reveals an in-frame 66 bp deletion, which results from the use of a cryptic GT splice donor site within exon 63.

Our siblings also differ from the 4 reports of HSAN-IV caused by DST mutations (table 2). A homozygous frameshift mutation near the end of an SR domain (p.E4995fsX28 when annotated in isoform a1 or p.E5133fsX28 annotated in isoform a2) likely affects all BPAG1a and BPAG1b isoforms (figure $2 \mathrm{~A}$ ) in a single, consanguineous family. Affected infants have a severe and lethal phenotype-dysautonomia, feeding difficulties, respiratory insufficiency, distal contractures, hypotonia, absent deep tendon reflexes, and severe psychomotor retardation and facial paralysis. Subsequently, compound heterozygous DST mutations with milder, more discrete phenotypes have been reported in 3 families $^{6,7,10}$; all 


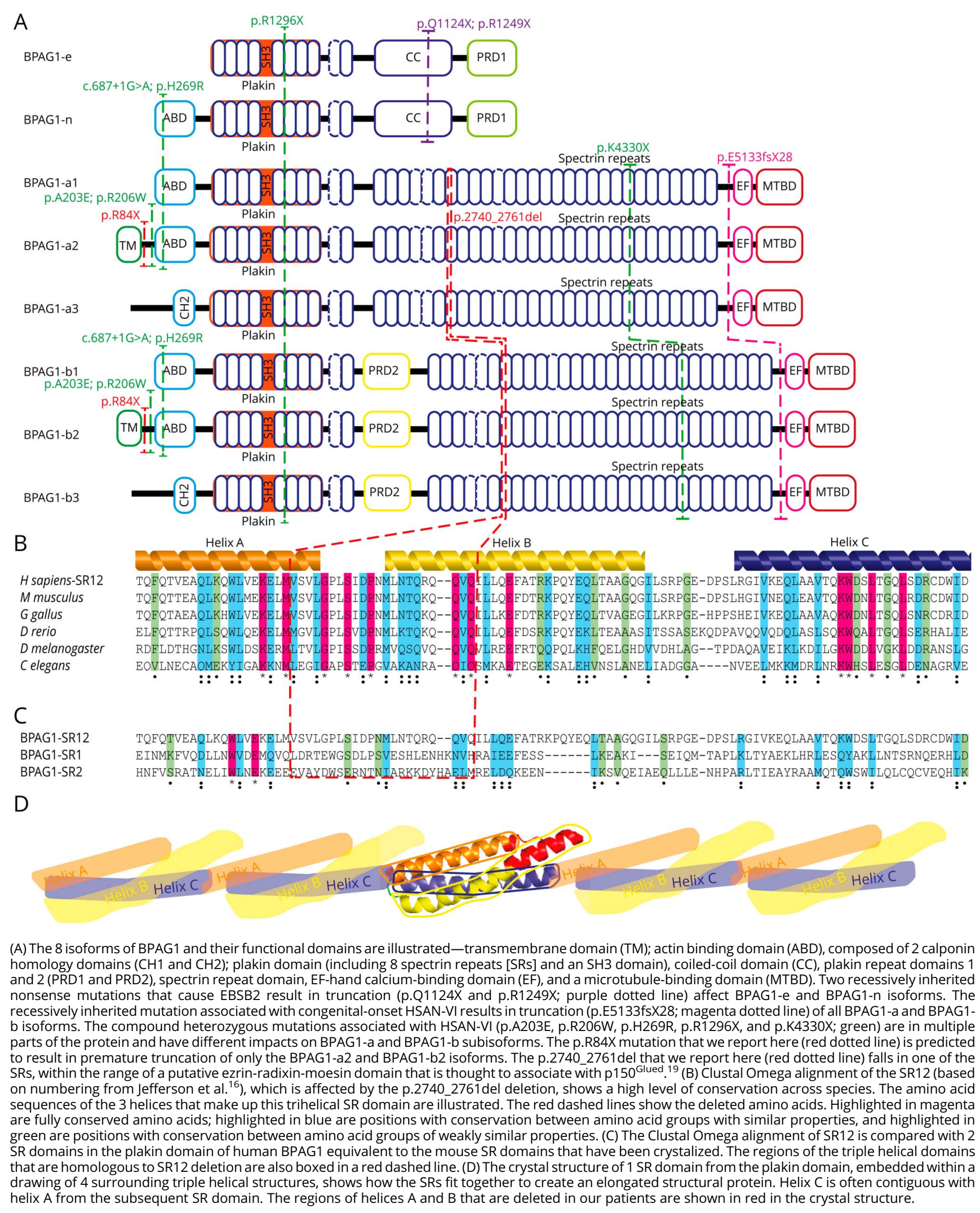

had normal growth without cognitive deficits or developmental delay, as well as a severe sensory neuropathy affecting small and large fibers and complicated by painful ulcerations and amputations of the distal extremities. They also have had prominent autonomic symptoms, including hyperhidrosis, hypohidrosis, heat intolerance, chronic 
Table 2 Genetic comparison of patients with DST-related neurologic disorders

\begin{tabular}{|c|c|c|c|c|c|c|c|c|c|}
\hline Phenotype & Phenotypic features & $\begin{array}{l}\text { CDNA } \\
\text { variants }\end{array}$ & $\begin{array}{l}\text { Predicted } \\
\text { protein } \\
\text { mutations }\end{array}$ & $\begin{array}{l}\text { BPAG1- } \\
\text { a1/b1 }\end{array}$ & $\begin{array}{l}\text { BPAG1- } \\
\text { a2/b2 }\end{array}$ & $\begin{array}{l}\text { BPAG1- } \\
\text { a3/b3 }\end{array}$ & $\begin{array}{l}\text { BPAG1- } \\
\text { e }\end{array}$ & $\begin{array}{l}\text { BPAG1- } \\
\mathrm{n}\end{array}$ & References \\
\hline $\begin{array}{l}\text { HSAN-VI + } \\
\text { additional } \\
\text { features }\end{array}$ & $\begin{array}{l}\text { Congenital onset, absent } \\
\text { tearing, blotching, feeding } \\
\text { difficulties, distal } \\
\text { contractures, facial paralysis, } \\
\text { psychomotor retardation, } \\
\text { absent reflexes, and early } \\
\text { death, no electrophysiology }\end{array}$ & $\begin{array}{l}\text { c.15399delA } \\
\text { c.15399delA }\end{array}$ & $\begin{array}{l}\text { p.E5133fs X28 } \\
\text { p.E5133fsX28 }\end{array}$ & $\begin{array}{l}- \\
-\end{array}$ & - & - & $\begin{array}{l}+ \\
+\end{array}$ & $\begin{array}{l}+ \\
+\end{array}$ & $\begin{array}{l}\text { Edvardson } \\
\text { et al. }{ }^{8}\end{array}$ \\
\hline HSAN-VI & $\begin{array}{l}\text { Onset first decade, absent } \\
\text { pupillary light reflexes, } \\
\text { severe pain insensitivity, } \\
\text { distal ulcerations, } \\
\text { amputations, joint } \\
\text { deformities, reduced pain, } \\
\text { touch, vibration, deep tendon } \\
\text { reflexes, severe sensory > } \\
\text { motor axonal neuropathy by } \\
\text { electrophysiology, reduced } \\
\text { CMAP amplitudes in feet, } \\
\text { hypohidrosis, chronic } \\
\text { diarrhea, and sexual } \\
\text { dysfunction }\end{array}$ & $\begin{array}{l}\text { c. } 616 C>T \\
\text { c. } 687+1 G>A\end{array}$ & $\begin{array}{l}\text { p.R206W } \\
\text { Undetermined }^{a}\end{array}$ & $\begin{array}{l}+ \\
-\end{array}$ & - & $\begin{array}{l}+ \\
+\end{array}$ & $\begin{array}{l}+ \\
+\end{array}$ & $\begin{array}{l}+ \\
-\end{array}$ & $\begin{array}{l}\text { Manganelli } \\
\text { et al. }^{7}\end{array}$ \\
\hline HSAN-VI & $\begin{array}{l}\text { Onset 3-4 decades, absent } \\
\text { pupillary light reflexes, } \\
\text { sensorineural hearing loss, } \\
\text { xerophthalmia, xerostomia, } \\
\text { severe pain insensitivity, poor } \\
\text { healing of distal ulcerations in } \\
\text { the feet, disarticulations and } \\
\text { amputations, hypohidrosis } \\
\text { and heat intolerance, sexual } \\
\text { dysfunction and } \\
\text { incontinence, severe sensory } \\
>\text { motor axonal neuropathy } \\
\text { by electrophysiology }\end{array}$ & $\begin{array}{l}\text { c. } 608 C>A \\
\text { c. } 12988 A>T\end{array}$ & $\begin{array}{l}\text { p.A203E } \\
\text { p.K4330X }\end{array}$ & $\begin{array}{l}+ \\
-\end{array}$ & - & $\begin{array}{l}+ \\
-\end{array}$ & $\begin{array}{l}+ \\
+\end{array}$ & $\begin{array}{l}+ \\
+\end{array}$ & $\begin{array}{l}\text { Fortugno } \\
\text { et al. }^{6}\end{array}$ \\
\hline $\begin{array}{l}\text { HSAN-VI + } \\
\text { additional } \\
\text { features }\end{array}$ & $\begin{array}{l}\text { Onset first decade, } \\
\text { congenital cataracts, } \\
\text { syringomyelia, short stature, } \\
\text { delayed bone age, reduced } \\
\text { growth hormone secretion, } \\
\text { bilateral sensorineural } \\
\text { hearing loss, } \\
\text { electrodiagnostic evidence of } \\
\text { sensory axonal neuropathy, } \\
\text { normal deep tendon reflexes, } \\
\text { chronic diarrhea, blistering } \\
\text { skin, and ulcers }\end{array}$ & $\begin{array}{l}\text { c. } 806 \mathrm{~A}>\mathrm{G} \\
\text { c. } 3886 \mathrm{C}>\mathrm{T}\end{array}$ & $\begin{array}{l}\text { p.H269R } \\
\text { p.R1296X }\end{array}$ & $\begin{array}{l}- \\
-\end{array}$ & $\begin{array}{l}- \\
-\end{array}$ & $\begin{array}{l}+ \\
-\end{array}$ & $\begin{array}{l}+ \\
-\end{array}$ & $\begin{array}{l}- \\
-\end{array}$ & $\begin{array}{l}\text { Cappuccio } \\
\text { et al. }{ }^{9,10}\end{array}$ \\
\hline AR-CMT2 & $\begin{array}{l}\text { Onset second decade of } \\
\text { motor and sensory } \\
\text { neuropathy, cerebellar } \\
\text { findings appeared much later }\end{array}$ & $\begin{array}{l}\text { c. } 250 C>T \\
\text { c. } 8283+1 G>A\end{array}$ & $\begin{array}{l}\text { p.R84X } \\
\text { p.2740-2761 del }\end{array}$ & $\begin{array}{l}+ \\
-\end{array}$ & $\begin{array}{l}- \\
-\end{array}$ & $\begin{array}{l}+ \\
-\end{array}$ & $\begin{array}{l}+ \\
+\end{array}$ & $\begin{array}{l}+ \\
+\end{array}$ & This work \\
\hline
\end{tabular}

Abbreviations: $\mathrm{CDNA}=$ complementary DNA; CMAP = compound muscle action potential; $\mathrm{CMT}=$ Charcot-Marie-Tooth.

The phenotypes, mutations, and predicted effects on the various BPAG1 isoforms (+ = predicted to be unaffected; $-=$ predicted to be affected) are shown. ${ }^{a}$ See figure e-1 (links.Iww.com/NXG/A304).

diarrhea, sexual dysfunction, and absent pupillary light reflexes. In 1 of these 3 families, 1 mutation (p.H269R) affects $\mathrm{a} 1, \mathrm{~b} 1, \mathrm{a} 2, \mathrm{~b} 2$, and $\mathrm{n}$ isoforms, whereas the second mutation (p.R1269X) affects the plakin domain, which is present in all isoforms; this patient had complex phenotype with blistering skin and some unique phenotypic features-including congenital cataracts, syringomyelia, and reduced growth hormone secretion. In the other 2 HSAN-IV families, one of the mutations (p.A203E and p.R206W) is predicted to selectively affect the a 2 and b2 isoform, and the other mutation is predicted to have additional effects: the p.K4330X mutation (paired with the p.A203E mutation) should affect all BPAGla and BPAG1b isoforms, and the c. $687+1 \mathrm{G}>\mathrm{A}$ mutation (paired with the p.R206W mutation) has an unknown effect (figure e-1, links.lww.com/NXG/A304, but should be restricted to the a1, a2, b1, b2, and $\mathrm{n}$ isoforms). Like these 2 HSAN-IV families, our family has 1 mutation (p.R84X) that selectively affects the $\mathrm{a} 2$ and $\mathrm{b} 2$ isoforms; the 
second mutation (p.2740-2761del) in our family should affect all BPAGla and BPAG1b isoforms.

Thus, the loss of a2 and b2 isoforms is correlated with axonal neuropathy (table 2; see also reference 25), and we infer that the additional phenotypes seen in the 2 families with additional features beyond HSAN1-IV likely owe to the additional loss of $\mathrm{a} 1 / \mathrm{b} 1, \mathrm{a} 3 / \mathrm{b} 3$, and/or $\mathrm{n}$ isoforms. This conclusion is in line with studies of recessive Dst mutations that produce the dystonia musculorum $(d t / d t)$ phenotype in mice-an earlyonset, progressive sensory neuropathy and ataxia notable for bizarre movements and abnormal postures. Pathologic analysis reveals that sensory neurons and their axons are the most affected, ${ }^{26}$ but spinocerebellar degeneration ${ }^{27}$ and motor axon involvement have been noted. ${ }^{28}$ Several $D s t$ alleles have been identified, and the ones have been characterized share functional deletion of all a1 and b1 isoforms, ${ }^{18}$ including $d t^{\operatorname{tg} 4 / \operatorname{tg} 4}$, which eliminates the expression of a1, a2, b1, and b2 (but not a3 and b3). ${ }^{29,30}$ Furthermore, expressing the $\mathrm{a} 2$ isoform as a transgene in neurons reduced the severity of $d t^{\operatorname{tg} 4 / \operatorname{tg} 4}$ phenotype. ${ }^{31}$ Thus, the loss of BPAG1-a2 specifically could be the cause of the neuropathy seen in $d t / d t$ mice and our patients; whether the loss of $\mathrm{b} 2$ contributes to the phenotype remains to be determined. Haploinsufficiency in several Dst alleles in mice has not been shown to cause any overt behavioral phenotypes, but $d t^{\text {tg } 4 /+}$ mice do have subtle ultrastructural defects in myelination of ventral roots and reduced axon caliber. $^{32}$

Why somatic (motor and sensory) axons are more affected (and cerebellar axons are affected in one of our patients), whereas autonomic axons are not affected in our siblings, however, remains unexplained. The similarity between the mutations in the BPAG1-a2 and -b2 specific exons allows us to favor a hypothesis that the SR domain deletion (p.2740 $2761 \mathrm{del}$ ) confers this difference. The in-frame deletion in the SR domain produced by this mutation may result in a partial and selective loss of function, but how this mutation spares autonomic axons remains to be determined.

\section{Acknowledgment}

The authors thank their patients and their sibling for their participation in this study, as well as Drs. Arthur Asbury, Mark Brown, and Kenneth Fischbeck for performing the initial evaluations. They thank Drs. Ronald Liem and Rashmi Kothary for their help with the structure of the dystonin gene and protein. They also thank Matt C. Danzi for help analyzing the primary sequencing data.

\section{Study funding}

This work was supported by the Judy Seltzer Levenson Memorial Fund for CMT Research, the INC (U54NS065712), which is a part of the NCATS Rare Diseases Clinical Research Network (RDCRN), an initiative of the Office of Rare Diseases Research (ORDR), NCATS, funded through a collaboration between NCATS and the NINDS, and WWM was supported in part by NIH (NINDS) R25NS065729.

\section{Disclosure}

W.W. Motley is a full-time employee of Third Rock Ventures. S. Züchner and S.S. Scherer report no relevant disclosures. Go to Neurology.org/NG for full disclosure.

\section{Publication history}

Received by Neurology: Genetics March 8, 2020. Accepted in final form May 28, 2020.

Appendix Authors

\begin{tabular}{lll}
\hline Name & Location & Contribution \\
\hline $\begin{array}{l}\text { William W. } \\
\text { Motley, MD, } \\
\text { DPhil }\end{array}$ & $\begin{array}{l}\text { Third Rock } \\
\text { Ventures, Boston, } \\
\text { MA }\end{array}$ & $\begin{array}{l}\text { Study concept and design, } \\
\text { acquisition and analysis of data, } \\
\text { and drafting the manuscript and } \\
\text { figures }\end{array}$ \\
\hline $\begin{array}{l}\text { Stephan } \\
\text { Züchner, MD, } \\
\text { PhD }\end{array}$ & $\begin{array}{l}\text { University of } \\
\text { Miami, FL }\end{array}$ & $\begin{array}{l}\text { Study concept and design, } \\
\text { acquisition and analysis of data, } \\
\text { and review of the manuscript and } \\
\text { figures }\end{array}$ \\
\hline $\begin{array}{l}\text { Steven S. } \\
\text { Scherer, MD, } \\
\text { PhD }\end{array}$ & $\begin{array}{l}\text { University of } \\
\text { Pennsylvania, }\end{array}$ & $\begin{array}{l}\text { Study concept and design, } \\
\text { acquisition and analysis of data, } \\
\text { and drafting the manuscript and } \\
\text { figures }\end{array}$ \\
\hline
\end{tabular}

\section{References}

1. Saporta ASD, Sottile SL, Miller LJ, Feely SME, Siskind CE, Shy ME. CharcotMarie-Tooth disease subtypes and genetic testing strategies. Ann Neurol 2011;69: 22-33.

2. Rossor AM, Polke JM, Houlden H, Reilly MM. Clinical implications of genetic advances in Charcot-Marie-Tooth disease. Nat Rev Neurol 2013;9:562-571.

3. Stanley JR, Tanaka T, Mueller S, Klaus-Kovtun V, Roop D. Isolation of complementary DNA for bullous pemphigoid antigen by use of patients' autoantibodies. J Clin Invest 1988;82:1864-1870.

4. Liu L, Dopping-Hepenstal PJ, Lovell PA, et al. Autosomal recessive epidermolysis bullosa simplex due to loss of BPAG1-e expression. J Invest Derm 2012;132: $742-744$.

5. Groves RW, Liu L, Dopping-Hepenstal PJ, et al. A homozygous nonsense mutation within the dystonin gene coding for the coiled-coil domain of the epithelial isoform of BPAG1 underlies a new subtype of autosomal recessive epidermolysis bullosa simplex. J Invest Derm 2010;130:1551-1557.

6. Fortugno P, Angelucci F, Cestra G, et al. Recessive mutations in the neuronal isoforms of DST, encoding dystonin, lead to abnormal actin cytoskeleton organization and HSAN type VI. Hum Mutat 2018;40:106-114.

7. Manganelli F, Parisi S, Nolano M, et al. Novel mutations in dystonin provide clues to the pathomechanisms of HSAN-VI. Neurology 2017;88:2132-3240.

8. Edvardson S, Cinnamon Y, Jalas C, et al. Hereditary sensory autonomic neuropathy caused by a mutation in dystonin. Ann Neurol 2012;71:569-572.

9. Cappuccio G, Pinelli M, Torella A, et al. Expanding the phenotype of DST-related disorder: a case report suggesting a genotype/phenotype correlation. Am J Med Genet A 2019;182:268.

10. Cappuccio G, Pinelli M, Torella A, et al. Expanding the phenotype of DST-related disorder: a case report suggesting a genotype/phenotype correlation. Am J Med Genet A 2017;173:2743-2746.

11. Li H, Durbin R. Fast and accurate long-read alignment with Burrows-Wheeler transform. Bioinform 2010;26:589-595.

12. McKenna A, Hanna M, Banks E, et al. The Genome Analysis Toolkit: a MapReduce framework for analyzing next-generation DNA sequencing data. Genome Res 2010; 20:1297-1303.

13. Gonzalez M, Falk MJ, Gai X, Postrel R, Schüle R, Zuchner S. Innovative genomic collaboration using the GENESIS (GEM.app) platform. Hum Mutat 2015;36: 950-956.

14. Sonnenberg A, Liem RKH. Plakins in development and disease. Exp Cell Res 2007; 313:2189-2203.

15. Jefferson JJ, Leung CL, Liem RKH. Dissecting the sequence specific functions of alternative $\mathrm{N}$-terminal isoforms of mouse bullous pemphigoid antigen 1. Exp Cell Res 2006;312:2712-2725.

16. Jefferson JJ, Ciatto C, Shapiro L, Liem RKH. Structural analysis of the plakin domain of bullous pemphigoid antigen1 (BPAG1) suggests that plakins are members of the spectrin superfamily. J Mol Biol 2007;366:244-257. 
17. Murphy SM, Herrmann DN, McDermott MP, et al. Reliability of the CMT neuropathy score (second version) in Charcot-Marie-Tooth disease. J Peripher Nerv Syst 2011;16:191-198.

18. Young KG, Kothary R. Dystonin/Bpag1-a link to what? Cell Motil Cytoskel 2007; 64:897-905.

19. Liu J-J, Ding J, Kowal AS, et al. BPAG $\ln 4$ is essential for retrograde axonal transport in sensory neurons. J Cell Biol 2003;163:223-229.

20. Liu J-J, Ding J, Wu C, et al. Retrolinkin, a membrane protein, plays an important role in retrograde axonal transport. Proc Nat Acad Sci USA 2007;104:2223-2228.

21. Ryan SD, Ferrier A, Sato T, et al. Neuronal dystonin isoform 2 is a mediator of endoplasmic reticulum structure and function. Mol Biol Cell 2012;23:553-566.

22. Baker KE, Parker R. Nonsense-mediated mRNA decay: terminating erroneous gene expression. Curr Opin Cell Biol 2004;3:293-299.

23. Nicolas A, Raguénès-Nicol C, Yaou RB, et al. Becker muscular dystrophy severity is linked to the structure of dystrophin. Hum Mol Genet 2014;24:1267-1279.

24. Takeichi T, Nanda A, Liu L, et al. Founder mutation in dystonin-e underlying autosomal recessive epidermolysis bullosa simplex in Kuwait. Br J Dermatol 2014;172:527-531.

25. Lynch-Godrei A, Kothary R. HSAN-VI: a spectrum disorder based on dystonin isoform expression. Neurol Genet 2020;6:e389. doi: 10.1212/NXG.0000000000000389.
26. Duchen L, Strich SJ, Falconer DS. Clinical and pathological studies of an hereditary neuropathy in mice (dystonia musculorum). Brain 1964;87:367-378.

27. Sotelo C, Guenet JL. Pathologic changes in the CNS of dystonia musculorum mutant mouse: an animal model for human spinocerebellar ataxia. Neuroscience 1988;27: 403-424.

28. Repentigny YD, Ferrier A, Ryan SD, Sato T, Kothary R. Motor unit abnormalities in Dystonia musculorum mice. PLoS One 2011;6:e21093.

29. Kothary R, Clapoff S, Brown A, Campbell R, Peterson A, Rossant J. A transgene containing lacZ inserted into the dystonia locus is expressed in neural tube. Nature 1988;335:435-437.

30. Brown A, Bernier G, Mathieu M, Rossant J, Kothary R. The mouse dystonia musculorum gene is a neural isoform of bullous pemphigoid antigen 1. Nat Genet 1995;10: 301-306.

31. Ferrier A, Sato T, Repentigny YD, et al. Transgenic expression of neuronal dystonin isoform 2 partially rescues the disease phenotype of the dystonia musculorum mouse model of hereditary sensory autonomic neuropathy VI. Hum Mol Genet 2014;23: 2694-2710.

32. Bernier G, Kothary R. Prenatal onset of axonopathy in Dystonia musculorum mice. Dev Genet 1998;22:160-168. 


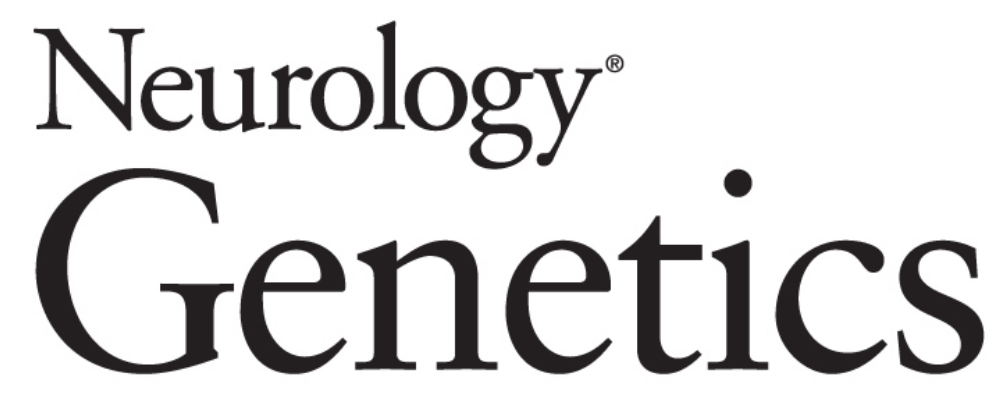

\section{Isoform-specific loss of dystonin causes hereditary motor and sensory neuropathy William W. Motley, Stephan Züchner and Steven S. Scherer Neurol Genet 2020;6; \\ DOI 10.1212/NXG.0000000000000496}

This information is current as of July 31, 2020

\section{Updated Information \& Services}

References

Citations

Subspecialty Collections

Permissions \& Licensing

Reprints including high resolution figures, can be found at: http://ng.neurology.org/content/6/5/e496.full.html

This article cites 32 articles, 5 of which you can access for free at: http://ng.neurology.org/content/6/5/e496.full.html\#\#ref-list-1

This article has been cited by 1 HighWire-hosted articles: http://ng.neurology.org/content/6/5/e496.full.html\#\#otherarticles

This article, along with others on similar topics, appears in the following collection(s):

\section{All Genetics}

http://ng.neurology.org//cgi/collection/all_genetics

All Neuromuscular Disease

http://ng.neurology.org//cgi/collection/all_neuromuscular_disease Peripheral neuropathy

http://ng.neurology.org//cgi/collection/peripheral_neuropathy

Information about reproducing this article in parts (figures,tables) or in its entirety can be found online at:

http://ng.neurology.org/misc/about.xhtml\#permissions

Information about ordering reprints can be found online: http://ng.neurology.org/misc/addir.xhtml\#reprintsus

Neurol Genet is an official journal of the American Academy of Neurology. Published since April 2015, it is an open-access, online-only, continuous publication journal. Copyright Copyright $\odot 2020$ The Author(s). Published by Wolters Kluwer Health, Inc. on behalf of the American Academy of Neurology.. All rights reserved. Online ISSN: 2376-7839.

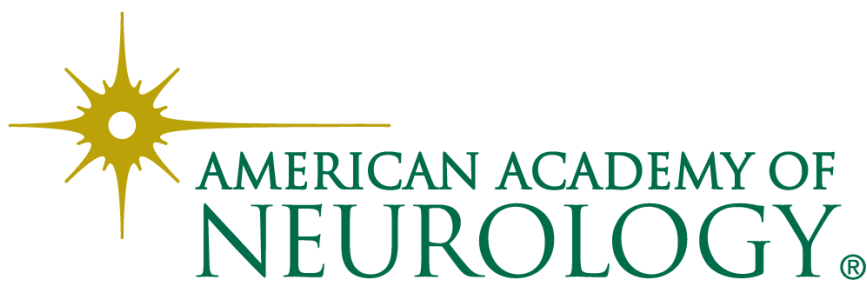

